\title{
PENGARUH PEMASANGAN SUDU PENGARAH DAN VARIASI JUMLAH SUDU ROTOR TERHADAP UNJUK KERJA TURBIN ANGIN SAVONIUS
}

\author{
Yunus Fallo', Bruno B. A. Liu², Dedy N. Ully ${ }^{3}$
}

\begin{abstract}
Abstrak :
Pemasangan sudu pengarah di depan sudu rotor dapat meningkatkan unjuk kerja turbin angin Savonius, karena dapat mencegah torsi negatif pada sudu cembung dan mengarahkan sejumlah massa udara pada sudu cekung tanpa mengenai sudu cembung. Penelitian ini dilakukan dengan menggunakan metode eksperimental nyata (true experimental) pada skala laboratorium. Hasil penelitian menunjukkan bahwa coefficient of power meningkat secara parabolik seiring bertambahnya kecepatan angin sehingga pada kecepatan 6 dan $7 \mathrm{~m} / \mathrm{s}$ mengalami penurunan. Hal ini terjadi karena meningkatnya kecepatan angin yang tidak diimbangi dengan kenaikan daya poros dan torsi. Pada rotor dengan pemasangan sudu pengarah coefficient of power maksimum terjadi pada rotor tiga sudu sebesar 0,2314, rotor dua sudu sebesar 0,1825, rotor empat sudu sebesar 0,12006. Di mana coefficient of power tertinggi ini terjadi pada kecepatan angin $5 \mathrm{~m} / \mathrm{s}$ kecuali rotor empat sudu. Sedangkan pada rotor tanpa pemasangan sudu pengarah coefficient of power maksimum juga terjadi pada rotor tiga sudu sebesar 0,18667, rotor dua sudu sebesar 0,1541 dan rotor empat sudu sebesar 0,0776. Coeficient of power maksimum pada rotor tiga dan dua sudu terjadi pada kecepatan angin $6 \mathrm{~m} / \mathrm{s}$, sedangkan rotor empat sudu coefficient of power maksimum terjadi pada kecepatan angin $7 \mathrm{~m} / \mathrm{s}$.
\end{abstract}

Kata kunci : Energi angin, Turbin angin Savonius, Sudu pengarah dan performance.

\begin{abstract}
:
Installation of the guide vane in front of the rotor blade can improve the performance of wind turbine Savonius, because it can prevent a negative torque on the blade is convex and directed a number of air mass on the concave blade without the blade convex. This research was conducted by using experimental methods real (true experimental) on a laboratory scale. The results showed that the efficiency of the parabolic increases with increasing wind speed so that the speed of 6 and $7 \mathrm{~m} / \mathrm{s}$ decline. This occurs due to the increased wind speed is not matched by the increase in BHP. In the rotor blade with the installation of directional maximum efficiency occurs at three rotor blades of $40.84 \%$, four-blade rotor of $34.42 \%$, two-blade rotor of $31.52 \%$. Where this occurs the highest efficiency at a wind speed of $5 \mathrm{~m} / \mathrm{s}$. While on the rotor blade without the installation of directional maximum efficiency occurs at three rotor blades of $37.39 \%$, two-blade rotor of $25.36 \%$ and a four-blade rotor amounted to $18.009 \%$. Maximum efficiency at three and two rotor blade occurs at a wind speed of $5 \mathrm{~m} / \mathrm{s}$, while the four-blade rotor maximum efficiency occurs at a wind speed of $6 \mathrm{~m} / \mathrm{s}$.
\end{abstract}

Keywords : Energi angin, Turbin angin Savonius, Sudu pengarah dan performance. 


\section{PENDAHULUAN}

Berdasarkan penelitian yang dilakukan Patil., 2008; mengatakan bahwa pengembangan pembangkit listrik tenaga angin sudah banyak dilakukan dengan menggunakan turbin angin poros horisontal, dimana turbin angin jenis ini mempunyai keunggulan yaitu memiliki perbandingan antara luas penampang propeller dengan luas area sapuan angin yang kecil serta memiliki perbandingan antara kecepatan keliling propeller dengan kecepatan angin yang besar sehingga dapat menghasilkan power coefficient (Cp) yang tinggi. Namun, turbin angin jenis ini juga memiliki kelemahan yaitu menghasilkan torsi yang relatif rendah dan membutuhkan perencanaan desain yang matang agar pemasangan turbin angin poros horisontal dapat berhasil dengan baik. Sementara itu, turbin angin Savonius yang memiliki poros vertikal mengalami kemajuan yang sangat pesat terutama peningkatan efisiensi dan aplikasinya yang banyak digunakan sebagai pembangkit listrik ataupun untuk keperluan lain misalnya sebagai penggerak pompa air untuk tujuan irigasi.

Menurut pendapat Hau., 2005; mengatakan bahwa turbin angin Savonius adalah sebuah mesin fluida yang memiliki sumbu poros vertikal yang diciptakan oleh seorang insinyur Filandia yang bernama Sigurd Johanes Savonius pada tahun 1922. Turbin angin Savonius ini memanfaatkan udara bebas sebagai fluida kerja. Udara yang bergerak dengan kecepatan $(v)$ dan massa $(m)$ tertentu memiliki energi kinetik yang dapat dikonversikan menjadi energi mekanik dengan menggunakan rotor turbin yang selanjutnya dikonversikan menjadi energi listrik.

Menurut pendapat Nursuhud dan Pudjanarsa., 2008; mengatakan bahwa turbin angin Savonius memiliki desain yang sederhana sehingga biaya investasinya lebih murah. Selain itu, turbin angin Savonius juga dapat beroperasi pada kecepatan angin yang rendah di mana pada kecepatan angin $2,7 \mathrm{~m} / \mathrm{s}$ atau $10 \mathrm{~km} / \mathrm{jam}(6$ m.p.h) maka turbin angin Savonius sudah dapat berputar dan menghasilkan energi listrik. Namun turbin angin Savonius juga memiliki kelemahan yaitu memiliki torsi awal yang kecil dan tidak mengambil keuntungan ketika adanya kecepatan yang tinggi karena efisiensinya cenderung menurun seiring naiknya kecepatan angin. Efisiensi turbin angin Savonius juga lebih rendah jika dibandingkan dengan turbin angin tipe propeller yang memiliki sumbu poros horisontal, sehingga dilakukan berbagai upaya untuk meningkatkan efisiensi dari turbin angin Savonius.

Upaya peningkatan efisiensi turbin angin Savonius sudah banyak dilakukan salah satunya oleh Saha dan Rajkumar., 2006; melakukan penelitian tentang penggunaan sudu rotor berbentuk elliptical, kemudian membandingkan dengan sudu rotor konvensional yang berbentuk setengah lingkaran. Dari hasil penelitian menunjukkan bahwa power coefficient yang dihasilkan sudu rotor berbentuk elliptical lebih tinggi dari pada sudu rotor konvensional. Pada sudu rotor berbentuk elliptical maka power coefficient dapat mencapai 0,1399 sedangkan pada sudu rotor konvensional hanya menghasilkan power coefficient sebesar 0,1104, di mana keduanya terjadi pada kecepatan angin $8,23 \mathrm{~m} / \mathrm{s}$.

Selanjutnya Kamoji et al., 2009; melakukan penelitian dengan membandingkan ketiga desain yaitu sudu rotor konvensional, modifikasi sudu rotor konvensional tanpa poros dan modifikasi sudu rotor konvensional dengan menggunakan poros, di mana pada penelitian ini tidak dilakukan pemasangan sudu pengarah. Hasilnya menunjukkan bahwa modifikasi sudu rotor konvensional tanpa poros memiliki performance yang lebih baik dari pada sudu rotor konvensional dan modifikasi sudu rotor dengan menggunakan poros.

Selanjutnya Mohamed et al.,2010; melakukan penelitian tentang optimasi turbin angin Savonius konvensional dengan menggunakan sudu pengarah untuk melindungi sudu cembung pada rotor turbin dari tumbukan angin. Karena akan ada torsi negatif apabila sudu cembung terkena tumbukan angin yang menyebabkan terhambatnya gerakan rotor turbin angin Savonius. Dari hasil penelitian menunjukkan 


\section{1 | JUTEKS Jurnal Teknik Sipil Volume 2 Nomor 2 Oktober 2017}

bahwa terjadi peningkatan power coefficient (Cp) seiring dengan meningkatnya tip speed ratio (TSR). Penggunaan sudu pengarah jelas memberikan peningkatan performance yang lebih baik bila dibandingkan dengan rotor turbin angin Savonius yang tanpa menggunakan sudu pengarah.

Selanjutya Mahmoud et al., 2012; melakukan penelitian tentang studi eksperimental peningkatan performance turbin angin Savonius konvensional untuk menentukan parameter operasi yang paling efektif. Dari hasil eksperimental didapat bahwa rotor dengan jumlah dua sudu menghasilkan power coefficient yang lebih tinggi dari pada rotor dengan jumlah tiga sudu dan empat sudu. Selanjutnya rotor double stage menghasilkan performance yang lebih baik jika dibandingkan dengan rotor yang memakai single stage. Sudu rotor yang dipakai pada penelitian ini adalah sudu konvensional setengah lingkaran.

Selanjutnya Farid., 2014; melaukan penelitian tentang optimasi daya turbin angin Savonius dengan variasi celah dan perubahan jumlah sudu. Dari hasil penelitian ini menunjukkan bahwa turbin angin Savonius mampu menghasilkan daya listrik maksimum 5,67 Watt dengan jarak celah sudu $30 \mathrm{~mm}$ pada kecepatan angin $5,2 \mathrm{~m} / \mathrm{s}$ dan daya listrik minimum 0,1 Watt dengan celah sudu $0 \mathrm{~mm}$ pada kecepatan angin $3,5 \mathrm{~m} / \mathrm{s}$. Selain itu diperoleh juga kesimpulan bahwa semakin tinggi kecepatan angin maka efisiensi yang dihasilkan tidak semakin tinggi tapi justru mengalami penurunan.

\section{TINJAUAN PUSTAKA}

\subsection{Performance Turbin Savonius}

\subsubsection{Putaran Poros (n)}

Turbin angin Savonius akan berputar ketika ada angin dengan kecepatan tertentu , sehingga putaran poros yang dihasilkan rotor turbin Savonius dapat langsung diukur dengan menggunakan tachometer digital ketika rotor berputar.

\subsubsection{Tip Speed Ratio (ë)}

Tip speed ratio (rasio kecepatan ujung) adalah perbandingan kecepatan pada ujung rotor terhadap kecepatan udara bebas. Tip speed ratio dapat dihitung dengan rumus sebagai berikut:

$\lambda=\frac{\pi D n}{60 . v}$

Dengan:

$D$ : diameter rotor $(\mathrm{m})$;

$n$ :putaran poros (rpm);

$v:$ kecepatan aliran udara $(\mathrm{m} / \mathrm{s})$.

\subsubsection{Daya Angin ()}

Daya angin dapat didefinisikan sebagai energi yang dihasilkan per satuan waktu yaitu sebagai berikut:

$$
\begin{aligned}
& P_{w}=E \text { per satuan waktu } \\
& =\frac{1}{2} \rho \cdot A \cdot v^{3} \text { (Watt) } \\
& =\frac{N \cdot m}{d t k}=\frac{\text { Joule }}{d t k}=\text { Watt }
\end{aligned}
$$

Dengan:

$$
\begin{aligned}
& P_{W}: \text { daya angin }(\mathrm{Watt}) ; \\
& \rho: \text { kerapatan massa udara }\left(\mathrm{kg} / \mathrm{m}^{3}\right) \\
& v: \text { kecepatan aliran udara }(\mathrm{m} / \mathrm{s}) \\
& A: \text { luas penampang }\left(\mathrm{m}^{2}\right) .
\end{aligned}
$$

\subsubsection{Torsi $(\mathrm{T})$}

Turbin angin Savonius yang memanfaatkan energi kinetik angin untuk dirubah menjadi energi mekanik pada rotor turbin memiliki gaya keliling. Rotor yang berputar dengan laju $n$ (rpm) akan menghasilkan gaya keliling atau torsi, T sebesar :

$$
\begin{aligned}
& T=F x r(N . m) \\
& F=(m-s) \times g(N)
\end{aligned}
$$

\section{Dengan:}

$$
\begin{aligned}
& T=\text { torsi }(\mathrm{N} . \mathrm{m}) \\
& F=\text { gaya yang bekerja pada poros }(\mathrm{N}) \\
& m=\text { massa pembebanan }(\mathrm{kg}) ; \\
& r=\text { jari-jari puli }(\mathrm{m}) ; \mathrm{s}=\operatorname{spring}(\mathrm{kg}) \\
& g=\text { gaya gravitasi }(\mathrm{m} / \mathrm{s} 2) .
\end{aligned}
$$




\subsubsection{Daya Poros $(\mathrm{Pm})$}

Daya poros diukur dengan melakukan pembebanan pada poros untuk mendapat nilai torsi dan mengukur putaran pada poros untuk menghitung kecepatan angulernya. Selanjutnya, daya poros didapatkan dengan mengalikan antara nilai torsi dengan kecepatan angulernya seperti terlihat pada persamaan 2-30 di bawah ini:

$P_{m}=T \times \omega$

(Watt) (5)

$\omega=\frac{2 \times \pi \times n}{60}$

$(\mathrm{rad} / \mathrm{s})$

Dengan: $P_{m}=$ daya poros (Watt);

$\omega=$ kecepatan anguler $(\mathrm{rad} / \mathrm{s})$;

$n=$ putaran poros (rpm).

\subsubsection{Koefisien Daya (Coefficientof Power)}

Koefisien daya adalah hal penting dalam mendesain sebuah turbin angin karena menunjukkan seberapa besar energi kinetik angin yang dikonversikan menjadi daya poros dengan bantuan rotor turbin. Koefisien daya merupakan perbandingan antara energi yang digunakan (input) dengan energi yang dihasilkan (output). Rumus coefficient of power adalah sebagai berikut:

$$
\text { Cop }=\frac{P_{m}}{P_{w}}
$$

Dengan :

$$
\begin{aligned}
\text { Cop } & =\text { power coefficient } \\
P_{m} & =\text { daya poros (Watt) } \\
P_{w} & =\text { daya angin (Watt). }
\end{aligned}
$$

\subsection{Instrumen Penelitian}

Instrumen atau instalasi penelitian dapat dilihat pada gambar di bawah ini :

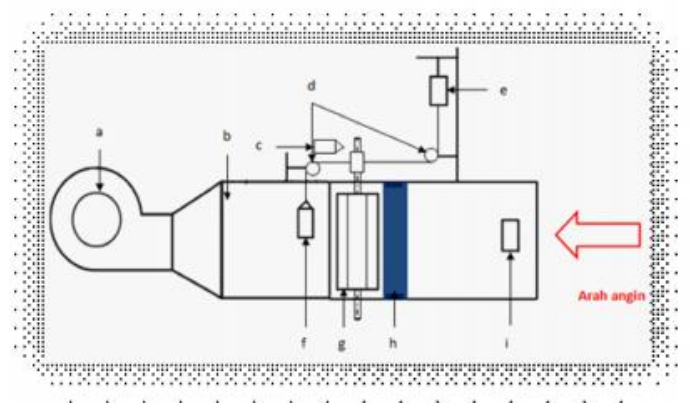

Gambar 1. Instalasi Penelitian

Keterangan gambar :

a.Blower

$b$. Wind tunnel (terowongan angin)

c. Tachometer digital

d.Puli

e. Spring balance

f. Massa pembebanan

g. Rotor turbin

h.Sudu Pengarah

i. Anemometer

Pada saat menghidupkan blower maka udara bebas yang memiliki kecepatan $(v)$ dan massa $(\mathrm{kg})$ tertentu akan terisap dan mengalir melalui wind tunnel (terowongan angin) sehingga dapat menggerakkan rotor turbin, selanjutnya memutar poros generator listrik untuk membangkitkan energi listrik seperti terlihat pada gambar 1. Dengan demikian terjadi perubahan atau konversi energi angin menjadi energi gerak dalam bentuk putaran poros. Selanjutnya putaran poros rotor akan melawan massa pembebanan. Massa pembebanan akan terus diberikan hingga mencapai top performance. Apabila melebihi top performance maka putaran rotor akan terus berkurang hingga rotor berhenti berputar. Nilai massa pembebanan akan dipakai untuk menghitung nilai torsi dan nilai putaran untuk menghitung kecepatan sudut ( $\mathrm{rad} / \mathrm{s})$, selanjutnya kecepatan sudut dipakai untuk menghitung daya poros (watt). Dengan demikian, maka massa pembebanan harus diberikan sedikit demi sedikit dan sangat teliti. Putaran rotor dan massa pembebanan akan dicatat pada masing-masing perlakuan sesuai dengan variasi kecepatan angin 
yang ditetapkan yaitu 4, 5, 6 dan $7 \mathrm{~m} / \mathrm{s}$ serta variasi jumlah sudu rotor yaitu 2, 3 dan 4 sudu baik dengan pemasangan sudu pengarah maupun tanpa pemasangan sudu pengarah. Dimensi sudu rotor yang dilengkapi dengan sudu pengarah seperti terlihat pada gambar 2 (a), (b) dan (c) :

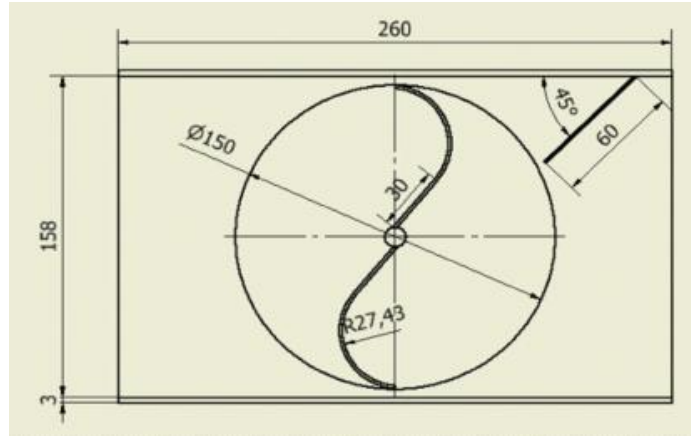

Gambar 2. (a). Dimensi rotor turbin dengan jumlah 2 sudu

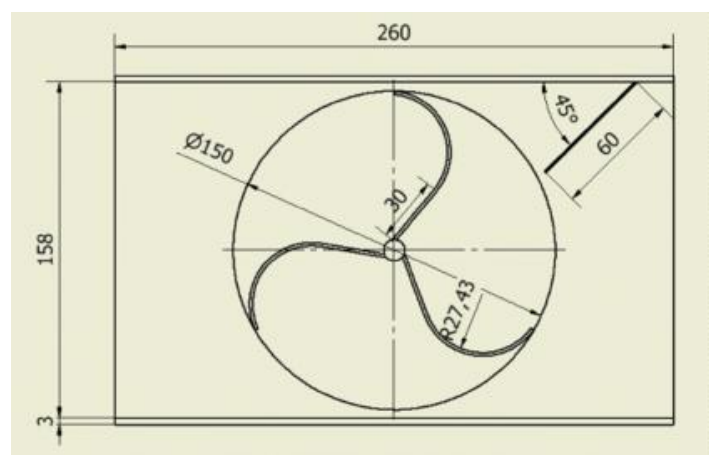

(b). Dimensi rotor turbin dengan jumlah 3 sudu

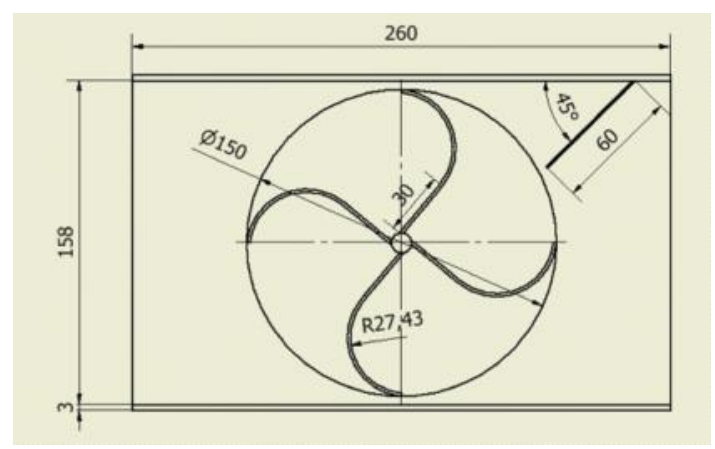

(c). Dimensi rotor turbin dengan jumlah 4 sudu

\section{Volume 2 Nomor 2 Oktober 2017}

\section{METODE PENELITIAN}

Penelitian ini dilakukan dengan menggunakan metode eksperimental nyata (true experimental) yaitu melakukan pengamatan untuk mencari data sebab akibat dalam suatu proses melalui eksperimen sehingga dapat mengetahui pengaruh pemasangan sudu pengarah dan variasi jumlah sudu rotor terhadap performance turbin angin Savonius tipe $\mathrm{L}$. dimana dilakukan perlakuan yang berbeda dengan cara divariasikan jumlah sudu rotor turbin kemudian dibandingkan, sehingga diperoleh suatu pola kejadian yang saling berhubungan.

Tujuan yang ingin dicapai dari penelitian skala laboratorium ini adalah agar dapat meningkatkan performance turbin angin Savonius dengan pemasangan sudu pengarah di depan sudu rotor turbin yang berfungsi untuk mencegah adanya torsi negatif pada sudu cembung yang dapat menghambat gerakan putaran rotor itu sendiri dan mengarahkan sejumlah massa udara pada sudu cekung tanpa mengenai sudu cembung seperti yang diutarakan oleh Altan et al., 2008.

\section{Variabel Penelitian}

Variabel Bebas :

Kecepatan angin : 4, 5, 6 dan $7 \mathrm{~m} /$.

Jumlah sudu rotor : 2,3 dan 4 sudu.

\section{Variabel Terikat :}

Tip speed ratio

Torsi (T),

Daya poros $(P m)$,

Efisiensi $(\eta)$

\section{HASIL DAN PEMBAHASAN}

Gambar 3 menunjukkan bahwa semakin tinggi kecepatan angin maka tip speed ratio naik secara parabolik, kecuali pada rotor empat sudu di mana grafiknya terlihat cenderung meningkat secara linear pada semua kecepatan angin. Hal ini terjadi karena turbulensi aliran udara terhadap sudu rotornya besar seiring meningkatnya kecepatan angin sehingga tidak mengalami peningkatan yang signifikan pula. 
Selain itu, jumlah sudu rotor yang lebih sedikit dapat mereduksi putaran yang dihasilkan karena jumlah angin yang diterima per detik lebih sedikit sehingga menimbulkan turbulensi dan penurunan pada kecepatan angin yang lebih tinggi.

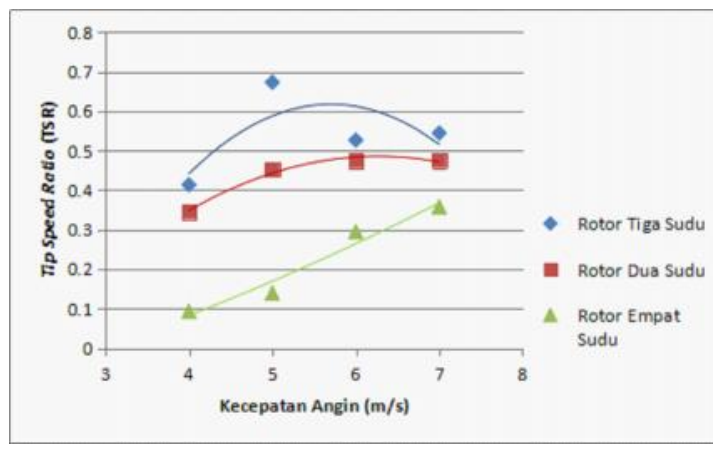

Gambar 3. Hubungan kecepatan angin terhadap TSR (Tanpa sudu pengarah)

Tip speed ratio sangat dipengaruhi oleh kecepatan angin, putaran rotor yang dihasilkan turbin angin Savonius. Pada rotor yang tanpa menggunakan sudu pengarah maka tip speed ratio tertinggi terjadi pada masing-masing variasi jumlah sudu : rotor tiga sudu yaitu 0,6727 , kemudian terjadi penurunan tip speed ratio pada rotor dua sudu yaitu 0.4745 dan tip speed ratio terendah terjadi pada rotor empat sudu yaitu 0,1389 . Semua tip speed ratio tertinggi terjadi pada kecepatan angin $6 \mathrm{~m} / \mathrm{s}$.

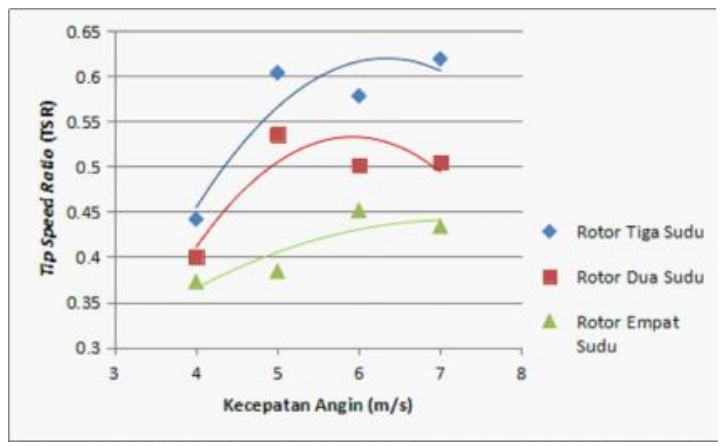

Gambar 4. Hubungan kecepatan angin terhadap TSR (Dengan sudu pengarah)
Jika dibandingkan dengan rotor yang tanpa menggunakan sudu pengarah (gambar 3) maka terlihat bahwa tip speed ratio juga meningkat secara parabolik kecuali pada rotor empat sudu yang meningkat secara linear. Hal ini terjadi karena adanya turbulensi udara yang sangat tinggi sehingga dengan bertambahnya kecepatan angin maka tip speed rationya cenderung tidak linear. Di sini juga terlihat bahwa rotor turbin yang menggunakan sudu pengarah dapat menghasilkan tip speed ratio rata-rata lebih tinggi dari pada rotor yang tanpa menggunakan sudu pengarah.

Tip speed ratio tertinggi terjadi pada masing-masing variasi jumlah sudu : rotor tiga sudu yaitu 0,619 pada kecepatan angin $7 \mathrm{~m} / \mathrm{s}$, kemudian terjadi penurunan tip speed ratio pada rotor dua sudu yaitu 0,535 pada kecepatan angin $5 \mathrm{~m} / \mathrm{s}$ dan tip speed ratio terendah terjadi pada rotor empat sudu yaitu 0.4512 pada kecepatan $6 \mathrm{~m} / \mathrm{s}$. Tip speed ratio sangat dipengaruhi oleh kecepatan angin, putaran rotor dan kecepatan sudut.

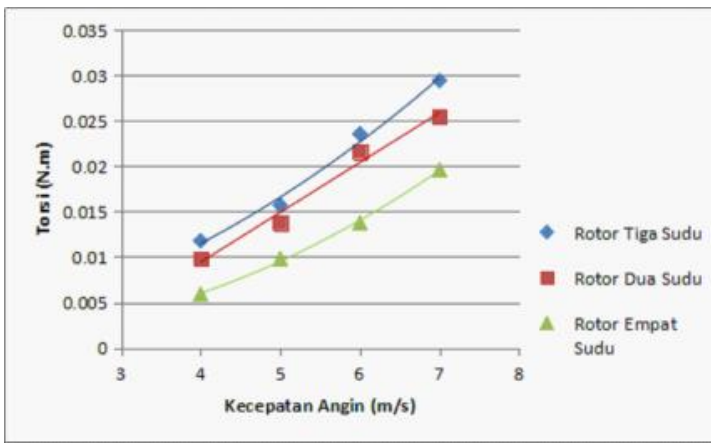

Gambar 5. Hubungan kecepatan angin terhadap torsi (Tanpa sudu pengarah)

Berdasarkan gambar 5 di bawah ini maka terlihat bahwa kecepatan angin sangat berpengaruh terhadap torsi yang dihasilkan oleh rotor turbin. Semakin tinggi kecepatan angin maka semakin tinggi pula torsi yang dihasilkn oleh turbin angin Savonius. Pada rotor turbin yang tanpa menggunakan sudu pengarah torsi tertinggi terjadi masing-masing variasi jumlah : rotor tiga sudu yaitu 0,02943 N.m, kemudian terjadi penurunan torsi pada rotor dua sudu 


\section{5 | JUTEKS Jurnal Teknik Sipil Volume 2 Nomor 2 Oktober 2017}

yaitu 0,0255 N.m dan torsi terendah terjadi pada rotor empat sudu yaitu 0,01962 N.m. Torsi tertinggi pada ketiga variasi jumlah sudu rotor ini terjadi pada kecepatan angin $7 \mathrm{~m} / \mathrm{s}$.

Dari grafik juga terlihat bahwa torsi meningkat secara linear pada ketiga variasi jumlah sudu rotor, hal ini terjadi karena penambahan kecepatan angin yang diimbangi dengan besarnya pengingkatan nilai massa pembebanan yang diberikan pada rotor turbin, sehingga berpengaruh terhadap peningkatan nilai torsi. Karena nilai torsi sangat dipengaruhi oleh nilai massa pembebanan yang diberikan. Pembebanan yang diberikan harus dilakukan sedikit demi sedikit agar putaran rotor turbin tidak menurun secara dratis dan bahkan berheti berputar.

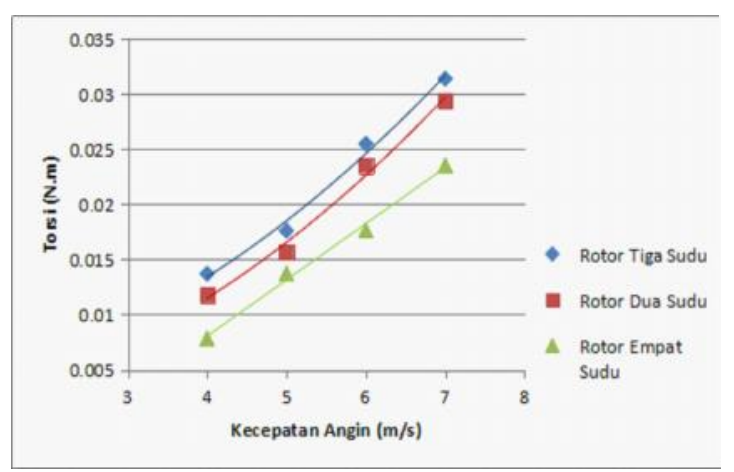

Gambar 6. Hubungan kecepatan angin terhadap torsi (Dengan sudu pengarah)

Berdasarkan gambar 6 di bawah terlihat maka bahwa kecepatan angin sangat berpengaruh terhadap torsi yang dihasilkan oleh rotor turbin. Pada rotor turbin yang menggunakan sudu pengarah torsi tertinggi terjadi pada masing-masing variasi jumlah sudu rotor : rotor tiga sudu yaitu 0,03139 N.m, kemudian terjadi penurunan torsi pada rotor dua sudu yaitu 0,02943 N.m dan torsi terendah terjadi pada rotor empat sudu yaitu 0.02354 . Semua torsi tertinggi terjadi pada kecepatan angin $7 \mathrm{~m} / \mathrm{s}$ pada masing-masing variasi jumlah sudu rotor.

Bila dibandingkan dengan rotor turbin yang tanpa menggunakan sudu pengarah (gambar 5) terlihat bahwa pada rotor turbin yang menggunakan sudu pengarah memiliki nilai torsi rata-rata lebih baik Hal ini terjadi karena pengaruh pemasangan sudu pengarah sehingga dapat mencegah torsi negatif pada sudu cembung dan mengarahkan sejumlah massa udara pada sudu cekung tanpa mengenai sudu cembung.

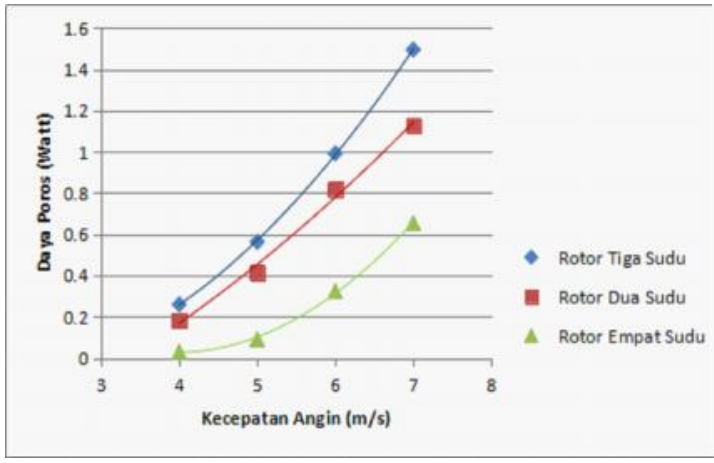

Gambar 7. Hubungan kecepatan angin terhadap daya poros (Tanpa sudu pengarah)

Berdasarkan gambar 7 maka terlihat bahwa kecepatan angin sangat berpengaruh terhadap daya poros yang dihasilkan oleh rotor turbin. Pada rotor turbin yang tanpa menggunakan sudu pengarah maka nilai daya poros tertinggi terjadi pada masing-masing variasi jumlah sudu : rotor tiga sudu yaitu 1,494 Watt, kemudian terjadi penurunan nilai daya poros pada rotor dua sudu yaitu 1,128 Watt dan nilai daya poros terendah terjadi pada rotor empat sudu yaitu 0,6544 Watt. Dari grafik juga terlihat bahwa nilai daya poros meningkat secara linear seiring bertambahnya kecepatan angin yang diberikan. Hal ini terjadi karena dengan semakin bertambahnya kecepatan angin maka putaran akan semakin bertambah sehingga memicu terjadinya peningkatan nilai torsi yang dihasilkan oleh rotor turbin. Dengan demikian maka secara otomatis nilai daya juga akan meningkat karena nilai daya poros sangat bergantung pada besarnya nilai torsi dan kecepatan sudut. 


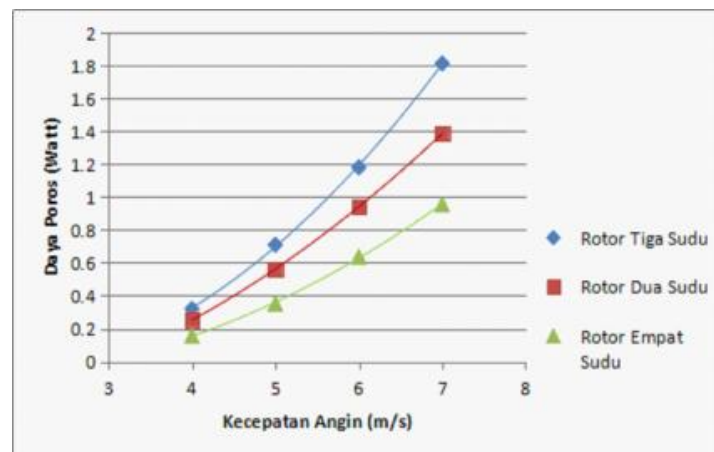

Gambar 8. Hubungan kecepatan angin terhadap daya poros (Dengan sudu pengarah)

Berdasarkan gambar 8 terlihat maka bahwa kecepatan angin juga sangat berpengaruh terhadap daya poros yang dihasilkan oleh rotor turbin. Pada rotor turbin dengan menggunakan sudu pengarah maka nilai daya poros tertinggi terjadi pada masing-masing variasi jumlah sudu : rotor tiga sudu yaitu 1,8138 Watt, kemudian terjadi penurunan pada rotor dua sudu yaitu 1,3859 Watt dan nilai daya poros terendah terjadi pada rotor empat sudu yaitu 0,955 Watt. Dari grafik juga terlihat bahwa nilai daya poros meningkat secara linear seiring bertambahnya nilai kecepatan angin yang diberikan.

Jika dibandingkan dengan grafik pada gambar 7 maka rotor dengan pemasangan sudu pengarah memiliki nilai daya poros lebih tinggi, hal ini terjadi akibat adanya peningkatan nilai torsi sehingga secara otomatis akan berpengaruh terhadap nilai daya poros yang dihasilkan oleh rotor turbin angin Savonius.

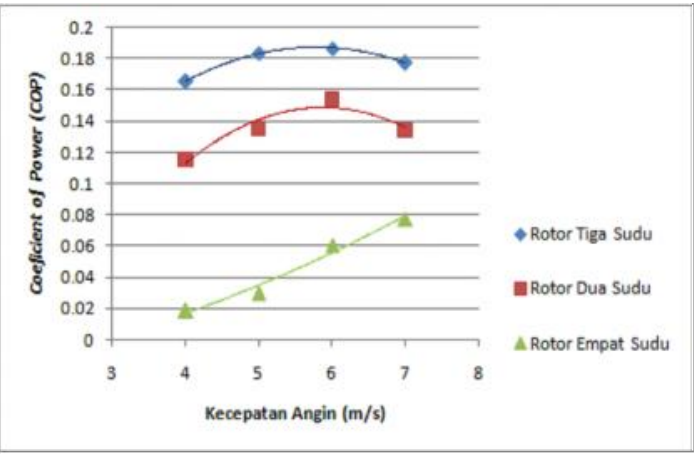

Gambar 9. Hubungan kecepatan angin terhadap COP (Tanpa sudu pengarah)
Berdasarkan gambar 9 maka terlihat bahwa kecepatan angin sangat berpengaruh terhadap coefficient of power yang dihasilkan oleh rotor turbin. Pada rotor turbin yang tanpa menggunakan sudu pengarah maka nilai coefficient of power tertinggi pada masingmasing variasi jumlah sudu rotor terjadi pada rotor tiga sudu yaitu 0,18667 , kemudian terjadi penurunan coefficient of power pada rotor dua sudu yaitu 0,1541 dan coefficient of power terendah terjadi pada rotor empat sudu yaitu 0,0776. Coeficient of power tertinggi pada variasi jumlah sudu rotor dua dan tiga ini terjadi pada kecepatan angin $6 \mathrm{~m} / \mathrm{s}$. Sedangkan coefficient of power tertinggi pada rotor empat sudu terjadi pada kecepatan angin $7 \mathrm{~m} / \mathrm{s}$.

Dari gambar di atas juga terlihat bahwa coefficient of power meningkat secara parabolik kecuali pada rotor empat sudu yang mengalami peningkatan secara linear. Adanya kecenderungan parabolik pada rotor dua dan tiga sudu karena kenaikan kecepatan angin yang tidak diimbangi dengan peningkatan nilai torsi dan daya poros.

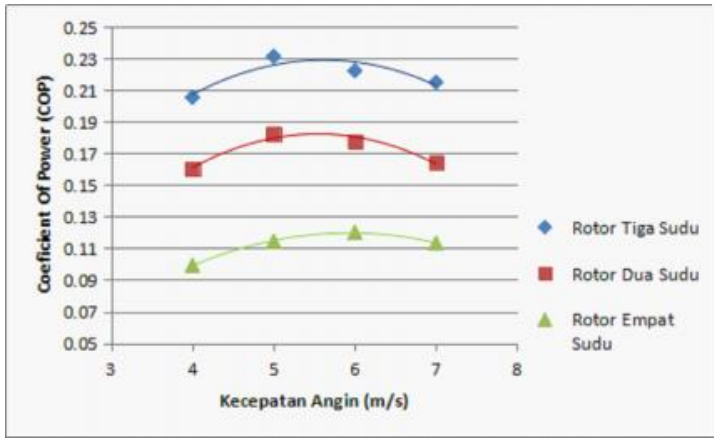

Gambar 10. Hubungan kecepatan angin terhadap efisiensi (Dengan sudu pengarah)

Berdasarkan gambar 10 maka terlihat bahwa kecepatan angin juga sangat berpengaruh terhadap coefficient of power yang dihasilkan oleh rotor turbin. Pada rotor turbin yang menggunakan sudu pengarah maka coefficient of power tertinggi terjadi pada masing-masing variasi jumlah sudu rotor yaitu rotor tiga sudu 0,255, kemudian terjadi penurunan coefficient 


\section{JUTEKS Jurnal Teknik Sipil Volume 2 Nomor 2 Oktober 2017}

of power pada rotor dua sudu yaitu 0,1825 dan coefficient of power terendah terjadi pada rotor empat sudu yaitu 0,12006 , di mana semua coefficient of power tertinggi terjadi kecepatan $5 \mathrm{~m} / \mathrm{s}$ kecuali rotor empat sudu yang terjadi pada kecepatan angin $6 \mathrm{~m} / \mathrm{s}$. Pada gambar 10 juga terlihat juga bahwa dengan adanya pertambahan kecepatan angin yang diberikan maka coefficient of power memiliki kecendrungan peningkatan secara parabolik, hal ini terjadi karena pertambahan kecepatan angin yang menyebabkan daya angin bertambah besar namun tidak diimbangi dengan kenaikan daya poros atau sehingga efisiensi cenderung mengalami penurunan.

Jika dibandingkan dengan grafik pada gambar 9, maka terlihat bahwa coefficient of power pada grafik gambar 10 memiliki nilai yang lebih tinggi, hal ini terjadi akibat penggunaan atau pemasangan sudu pengarah yang menyebabkan nilai torsi dan daya poros mengalami peningkatan, sehingga berpengaruh terhadap peningkatan nilai coeficint of power yang dihasilan rotor turbin Savonius.

\section{KESIMPULAN DAN SARAN}

\subsection{Kesimpulan}

Dari hasil pembahasan yang telah dilakukan maka dapat ditarik kesimpulan bahwa :

1.Pemasangan sudu pengarah di depan sudu rotor terlihat jelas dapat meningkatkan unjuk kerja turbin angin savonius, hal ini terjadi karena sudu pengarah dapat mencegah adanya torsi negatif pada rotor turbin karena sudu cembung juga terkena terpaan udara yang menyebabkan kehilangan torsi karena adanya gaya yang berlawanan dengan arah putaran rotor turbin.

2. Pada rotor yang menggunakan sudu pengarah maka unjuk kerja turbin angin Savonius maksimum terjadi pada masing-masing variasi jumlah sudu : rotor tiga sudu dengan coefficient of power 0,2314 dengan daya poros sebesar 0,7105 Watt pada kecepatan angin $5 \mathrm{~m} / \mathrm{s}$, kemudian menurun pada rotor dua sudu dengan coefficient of power sebesar 0,1825 dengan daya poros sebesar 0,56034 Watt juga pada kecepatan angin $5 \mathrm{~m} / \mathrm{s}$, sedangkan coeficient terendah terjadi pada rotor dengan jumlah empat sudu dengan coefficient of power sebesar 0,12006 dengan daya poros sebesar $0,6375 \mathrm{Watt}$ pada kecepatan $6 \mathrm{~m} / \mathrm{s}$.

3.Pada rotor tanpa menggunakan sudu pengarah unjuk kerja maksimum terjadi pada rotor tiga sudu dengan coefficient of power sebesar 0,18667 dengan daya poros sebesar 0,5632 Watt pada kecepatan angin $6 \mathrm{~m} / \mathrm{s}$, kemudian terjadi penurunan pada rotor dengan jumlah dua sudu dengan coefficient of power sebesar 0,1541 dengan daya poros sebesar 0,8183 Watt pada kecepatan angin $6 \mathrm{~m} / \mathrm{s}$, sedangkan coefficient of power terendah terjadi pada rotor empat sudu dengan coefficient of power sebesar 0,0776 dengan daya poros sebesar 0,6544 Watt pada kecepatan $7 \mathrm{~m} / \mathrm{s}$. Secara umum dapat diambil kesimpulan bahwa

\subsection{Saran}

Dari hasil penelitian tentang pengaruh pemasangan sudu pengarah dan variasi jumlah sudu rotor terhadap unjuk kerja turbin angin Savonius maka dapat disarankan sebagai berikut:

1.Perlu dilakukan penelitian lebih lanjut di mana udara yang dialirkan dari berbagai arah dan diberi variasi jumlah sudu pengarah.

2.Perlu dilakukan penelitian lebih lanjut dengan variasi besar sudut sudu pengarah terhadap sumbu rotor turbin.

3.Perlu dilakukan penelitian lebih lanjut dengan mengukur variabel torsi untuk mendapatkan nilai daya dengan menggunakan torsimeter.

\section{DAFTAR PUSTAKA}

Patil. H. S. 2008. Experimental work on horizontal axis $P V C$ turbine blade of power wind mill. International journal mechanical engineeering. ISSN 2277: 7059. 
Hau. E. 2005. Handbook Wind turbines fundamentals technologies, applications, economics. Springer Germany.

Nursuhud. D dan Pudjanarsa. A. 2008. Handbook Mesin Konversi Energi. Jakarta. Indonesia.

Saha U.K dan Rajkumar. J.M. 2006. On the performance analysis of Savonius rotor with twisted blades. Elsevier journal renewable energy 31 (2006) 1776-1788.

Kamoji. A.M; Kedare. B.S; Prabu. V.S. 2009. Experimental investigations on single stage modified Savonius Rotor. Elseiver journal applied energy 86 (2009) 1064-1073.

Mohamed. H.M; Janiga. G; Pap. E; Thevenin. D. 2010. Optimization of Savonius turbines using obstacle shielding the returning blade. Elsevier journal renewable energy 35 (2010) 2618-2626.
Mahmoud. H.N; El-Haroun. A.A; Wahba. E; Masef. H.M. 2012. An experimental study on improvement of.

Farid. 2014. Optimasi Daya Turbin Angin Savonius Dengan Variasi Celah dan Perubaha Jumlah Sudu. Prosiding SNST. ISBN 978-602-99334-3-7.

Altan. D.B; Atilgan M; Ozdamar A. 2008. An experimental study on improvement of a Savonius rotor performance with curtaining. Elsevier journal experimental thermal and fluid science 32 (2008) 16731678.

Petruzella D. F. 1996. Industrial Electronics. First Edition. Sumanto I. (penerjemah). 2002. Elektronik Industri. Edisi Pertama. ANDI Yogyakarta. 